\title{
The tourist gaze in English, Italian and German travel articles about Puglia: A corpus-based study ${ }^{1}$
}

\author{
Angela D'Egidio, University of Salento, Lecce
}

\section{Abstract}

This paper shows how online travel articles may provide important insights into how a tourist destination is perceived and to what extent what is known as the 'tourist gaze' may be used to recontextualise tourist material in order to produce more effective tourist texts, which meet receivers' expectations. For this purpose, three comparable corpora of online travel articles in English, Italian and German language were assembled and analysed in order to understand the way ordinary travellers perceive and experience a tourist destination in Italy (Puglia) by taking language as a point of reference. The first fifteen words of the frequency lists in the three corpora highlighted what landmarks and elements of attraction English, Italian and German travel writers gaze at while on holiday in Puglia. The analysis demonstrated that the Italian tourist gaze is different from the English and German tourist gazes, since not all of them focus on the same landscapes, and even when they gaze at the same sights, their perception and representation are often different. The similarities and differences between the ways the tourists behave suggest a distinction between a model of 'global gaze' embodied by English and German travellers, seen as 'outsiders', and a model of 'local gaze' embodied by Italian tourists, seen as 'insiders'.

\section{$1 \quad$ Introduction}

Tourism is both a significant component of modern life and an object of study and research, as it has become a part of the global process of change and development known as 'globalisation' which is no longer confined to the developed countries. Understanding what motivates people to travel is therefore a common challenge now faced by the tourist industry. In today's multicultural world, tourism organisations need new skills to communicate with customers, interact with stakeholders and promote tourist destinations. In recent years, the development of the Internet and the increasing number of people accessing the Internet have 
brought about some significant changes, not only in the way travellers from around the world leave a record of their personal experiences, but also how they obtain information on destinations.

Despite the large number of text genres in use, new text types emerge every year. In the world of tourism, according to Gotti (2006), the most popular publications are the following:

- $\quad$ Tourist guides - They describe places and give practical information;

- Brochures and other advertising materials - They are informative but also persuasive since their aim is to attract travellers;

- Professional correspondence - It is used between travel agencies, tour operators, hotels, and customers;

- Travel blogs or discussion forums - They are used to express opinions about travel, holiday destinations and services provided;

- Travel articles - They can be found in travel journals, in the travel section of newspapers or magazines, and provide a record of personal experiences.

\section{Travel articles: $A$ genre to identify the tourist gaze}

Travel articles are a specific type of tourist text genre, which can be found in the travel section of online newspapers and magazines, but also on websites dealing with tourism, travel and tourist destinations in general. According to Crowston and Williams (2000), they are listed in the web genre. More specifically, they are 'adapted' genres, as they have to adjust their 'offline' features to the affordances of the web.

Furthermore, travel articles are both pre-trip and on-trip texts. Their pre-trip function, which is primarily to stimulate interest and desire, is part of the process of preparation and anticipation which enables the visualisation of a destination. This allows readers to get a general idea about a place, to subsequently acquire knowledge and to create and keep the memory of the experience. Travel articles are also used on-trip as the maps of particular areas; the places to visit and the addresses of shops or restaurants cannot be memorised by the readers while reading online. In other words, they can serve as guides during the trip if travellers want to obtain more detailed information on certain aspects or activities they might be particularly interested in.

The writers of this text type are (semi-professional) travel reporters or travellers who send their articles to the newspaper editors to be published. In doing so, they leave a record of their travel experience, their emotions and their reac- 
tions to a place and its people. These authors are clearly recognised and their names are at the top or at the bottom of the articles.

What is worth mentioning is the predominance of subjectivity in travel articles and the focus on the writers and on what interested them as travellers. Therefore, readers are influenced implicitly and explicitly since they read only what travel writers choose to describe and say about a destination. To put it simply, the reality of the destination is filtered through subjectivity.

The present study explores the way Italian, English and German travel writers see and perceive a tourist destination - Puglia, in this case. The language used by travellers was analysed with the aim of identifying differences between the tourist gazes.

The notion of 'tourist gaze' was first introduced by sociologist John Urry (2002), who examined the concept of tourism from a sociological perspective in terms of perception, exploring the ideological and cultural dynamics that lead to a different approach to reality. He defines the 'gaze' as the most important tourist activity within the tourist experience. In other terms, the gazing process is what constitutes tourism. Indeed, when tourists 'are away', they privilege sight over other senses, gaze upon landscapes, places or objects, and observe the surrounding environment with "interest and curiosity" (2002: 1). Viewed as "the model of perception tourists adopt while performing the practice of sightseeing" (Francesconi 2007: 47), the 'tourist gaze' becomes one way of understanding the experiential elements of tourism and also helps explain why people visit certain environments and attach meanings to tourist settings. Objects suitable for the tourist gaze include unique objects, which are "famous for being famous" (Urry 2002: 12) and out-of-the-ordinary, particular signs, which tell tourists that what they are looking at is extraordinary and worth seeing, or unfamiliar aspects not typically encountered in daily life.

\section{Methodology}

\subsection{Corpora description}

Three comparable corpora compiled from English, Italian and German travel articles focusing on Puglia were collected and stored on the computer in electronic format. These articles were published in the period ranging from January 2000 to April 2009 on online national newspapers or tourism-related websites.

The British and German corpora had almost 70,000 running words respectively, while the Italian corpus had about 100,000 words. Since there was a difference between the three corpora, the data were normalised, i.e. brought to a common scale $-70,000$ - to make the data on different scales comparable. The 
texts contained in these corpora were used for linguistic analysis by means of WordSmith Tools 6.0 (Scott 2012), a concordance software program.

First of all, a word frequency list of each corpus was compiled to identify the most frequently occurring words used to speak about Puglia. Table 1 presents the first fifteen words in each corpus:

Table 1: English, Italian and German frequency lists

\begin{tabular}{|c|c|c|c|c|c|}
\hline \multicolumn{6}{|c|}{ TOP 15} \\
\hline \multicolumn{2}{|c|}{ ENGLISH } & \multicolumn{2}{|c|}{ ITALIAN } & \multicolumn{2}{|c|}{ GERMAN } \\
\hline Puglia & 237 & Mare & 277 & Apulien & 254 \\
\hline Trullo/i & 142 & Salento & 142 & Meer & 93 \\
\hline Olive & 100 & Spiaggia & 137 & Salento & 90 \\
\hline Wine & 78 & Puglia & 103 & Lecce & 88 \\
\hline Masseria/e & 75 & Lecce & 100 & Trullo/i & 83 \\
\hline Lecce & 73 & Costa & 95 & Otranto & 61 \\
\hline Beach & 73 & Otranto & 86 & Stein & 61 \\
\hline $\mathrm{Sea}$ & 67 & Chiesa & 84 & Wein & 60 \\
\hline Coast & 58 & Leuca & 77 & Strand & 58 \\
\hline Baroque & 57 & Gallipoli & 63 & Oliven & 57 \\
\hline Stone & 51 & Grotte & 54 & Barock & 54 \\
\hline Restaurant & 48 & Ristorante & 48 & Gallipoli & 48 \\
\hline Oil & 48 & Gargano & 46 & $\ddot{O l}$ & 46 \\
\hline Church & 43 & Barocco & 43 & Alberobello & 39 \\
\hline Food +cuisine & 56 & Cattedrale & 38 & Kuste & 37 \\
\hline Alberobello & 40 & Castello & 24 & Kirche & 35 \\
\hline
\end{tabular}

As observed in Table 1, the landmarks and elements of attraction English, Italian and German tourists focus on while on holiday in Puglia are Salento with its capital Lecce and other small towns such as Santa Maria di Leuca, Gallipoli, Otranto and Alberobello. Moreover, the semantic field of 'food and drink' can also be identified (wine, oil, olives, food, masseria, restaurant).

Once the data had been collected, a contrastive analysis was conducted following the methodology developed by Tognini Bonelli (2001) and further investigated in Tognini Bonelli and Manca (2002). In particular, concordance lines 
for the words chosen in each corpus were generated and their lexico-grammatical profile was investigated.

\section{Data analysis and results}

\subsection{Puglia landmarks}

While analysing the three corpora, it was interesting to note that Italian, English and German writers frequently use fixed forms to refer to Puglia, Salento, Lecce and Alberobello.

As already noted (D'Egidio 2009: 203-204), Salento is referred to as 'the tip of the heel of Italy', Puglia is 'the heel of Italy's boot', while Lecce is often called the 'Florence of the Baroque' or the 'Florence of the South', and Alberobello, a small town of drystone dwellings (trulli), is widely considered the 'trulli capital of the world'. These fixed forms represent a linguistic stereotypical feature that Margarito (2000: 34) termed "clichés d'appellation". They are proper names or labels "with a high degree of generalization whose formula-like conciseness helps memorisation, identification and comprehension since it becomes a synthetic etiquette" (ibid.). By means of these socially codified and widespread formulae, Puglia, Salento, Lecce and Alberobello can effectively "enter and uniquely occupy the semiotic space of the tourist gaze. They become sights as worth visiting thanks to these catchy and memorable language patterns" (D'Egidio 2009: 204).

In order to explore how English, Italian and German tourists describe the Salento peninsula and Lecce, these names were investigated in the three corpora at the lexico-collocational level. When describing Salento and Lecce, abstract nouns are used by all Italian writers but one (who used an adjective). Expressions such as un meraviglioso gioiello barocco (a wonderful Baroque jewel), una sorpresa (a surprise), un vero splendore (a real beauty), uno spettacolo del barocco (a Baroque sight) were found 28 times in total. Abstract nouns with strong positive connotations reveal the emotive effect that this area has on Italian tourists. The frequent use of abstraction in Italian confirmed what Manca (2007) suggests in her analysis of the concepts of beauty and tranquillity on websites of British and Italian farmhouse holidays. Thus, nominalisation is used to convey perceptions and emotions rather than simple facts.

Following the methodology developed by Tognini Bonelli and Manca (2002) and further investigated in Manca (2008), the prima-facie translation of each of the abstract nouns mentioned above was investigated in the English and German corpora. Table 2 summarises the comparison of the results in the three corpora: 
Table 2: Prima-facie translation of Italian abstract nouns used to describe Salento and Lecce

\begin{tabular}{|ll|l|l|}
\hline ITALIAN & ENGLISH & GERMAN \\
\hline Gioiello & 9 & Jewel $\quad 2$ & Kostbarkeit \\
\hline Sorpresa & 7 & Surprise & Überraschung \\
\hline Splendore & 8 & Splendour 1 & Pracht \\
\hline Spettacolo & 4 & Sight & Anblick \\
\hline
\end{tabular}

Table 2 shows that the prima-facie translation of the Italian abstract nouns was not found except for two occurrences of jewel and one occurrence of splendour in the English corpus, and one occurrence of Pracht (in the compound word Prachtstück) in the German corpus. This seems to suggest that either those concepts are not expressed in the English and German corpora or they are expressed in a different way.

The analysis of the collocates of Salento and Lecce in the other two corpora showed that German and English tourists prefer to use adjectives, such as undiscovered, isolated, tourist-free and forgotten, which can be considered as opinions through which we understand English and German tourists' perspective. Also, this sort of environmental purity may be interpreted as an appealing feature. The above-mentioned adjectives along with others such as pristine, untouched, unexploited, undeveloped and wild occurred 34 times in total and were also retrieved among the collocates of the words sea, beach and coast. These adjectives underline the need German and English tourists have for authenticity and "a less touristy alternative to the jam-packed old Tuscany" (Gorton 2007: 1). According to Collins COBUILD advanced dictionary of English (2012:1657), "if you describe a place as 'touristy', you do not like it because it is full of tourists or full of things for tourists to buy and do". This means that English and German tourists tend to look for unique places which are not 'touristy'.

As already mentioned, Otranto, Santa Maria di Leuca and Alberobello (with its trulli) are other small towns visited by Italian, English and German tourists when in Puglia, even though not all of them are among the top fifteen words in the frequency lists. For example, Otranto, Italy's most easterly city, is among the first fifteen words of the Italian and German frequency lists, while it only has a six per cent occurrence in the English corpus. As in examples (1), (2) and (3), when in Otranto, the Italian gaze is mainly on the landscape (56\%), that is to say, on the beaches, sea and coast: 
(1) La costa indruntina è caratterizzata da scogliere alternate a spiagge bianchissime (The Otranto coast is characterized by rocks alternating with very white beaches).

(2) Bellissima, spiaggia bianca e mare stupendo (Very nice, white beach and wonderful sea).

(3) Tratto di costa a scogliera, dove l'acqua assume tutte le tonalità dell'azzurro (Rocky coastline where the water takes on the various shades of blue).

Moreover, 50 per cent of Italian tourists underline the 'touristy' aspect of this fortified town but not as a negative feature, by mentioning the chance to buy souvenir gifts. Examples (4) to (6) illustrate this tendency:

(4) Otranto è il labirinto di viuzze che ti invitano a scoprire il centro storico e i mille negozietti di artigianato locale (Otranto is a maze of narrow streets that encourage you to discover the old town centre and a thousand small local handicraft shops).

(5) Il passeggiare sarà l'occasione per visitare i numerosi negozietti (Strolling will be the way to visit many small shops).

(6) Il centro storico brulicante di turisti alla ricerca di souvenir (The old town centre crawling with tourists looking for souvenir gifts).

What emerges here is the gaze of Italian tourists on souvenir shops. The visit to this sight is encouraged by the opportunity to purchase local produce. This can be defined as the 'stage of mechanical reproduction' which MacCannel (1989: 44) includes in a five-stage conversion of sights into a tourist attraction, a process that he calls 'sight sacralisation'. Relatively few Italian tourists focus on the Aragonese Castle (25\%), visit the Romanesque Cathedral (18\%) or admire its mosaic pavement $(6 \%)$.

There was however no reference to souvenir shops in the German corpus. Similarly to Italians, elements of attraction for Germans are the landscape (40\%) and the Aragonese Castle (26\%). Interestingly, German tourists are more interested in the Romanesque Cathedral (26\%) and in the mosaic pavement $(33 \%)$ than Italians, as demonstrated in examples (7) to (9):

(7) In der Kathedrale von Otranto kann der Besucher einen vollständig erhaltenen Mosaikfußboden finden (In the cathedral in Otranto the visitor can find a perfectly preserved mosaic floor). 
(8) Hier die romanische Kathedrale mit dem faszinierenden Fußbodenmosaik (Here the Romanesque cathedral with its fascinating mosaic floor).

(9) Otranto $[\ldots]$ weltberühmtes Bodenmosaik der Kathedrale (Otranto $[\ldots]$ the cathedral's world-known mosaic floor).

The analysis of the collocational profile of the small town of Santa Maria di Leuca was only carried out in the Italian corpus since there were few occurrences in the other two corpora. The analysis showed that all the Italian tourists were attracted by the sea, grottos and the surrounding landscape, and that 30 per cent of them mentioned (but very few visited) the 'Sanctuary of Santa Maria di Leuca', the biggest church in this town.

Subsequently, Alberobello, the small village of drystone dwellings known as trulli, was analysed, as in all three corpora expressions are found showing how Alberobello and trulli are perceived and evaluated by English, Italian and German tourists. Italian tourists are attracted by the 'fairytale' aspect of the village and souvenir shops in 71 per cent of cases. Yet, these "are not perceived as a negative aspect but as something that encourages their visit to Alberobello" (D'Egidio 2009: 209). Most of the English and German writers (68\% and 73\% respectively), instead, define Alberobello as the most 'touristy' town in Puglia and denigrate the massification of tourism when talking about trulli, which have now been transformed into souvenir shops, restaurants, hotels, as examples (10) to (14) illustrate:

(10) Ruined by its proliferation of trinket shops.

(11) The rather tacky tourist souvenirs sold from them.

(12) Die Trulli sind ziemlich touristisch überlaufen (Trulli are quite overcrowded with tourists).

(13) Es gibt eine Menge "touristisch" Geschäfte (There is a large number of "tourist" shops).

(14) Man könnte ein wenig müde von Souvenirshops und ein bisschen irritierte Verkäufer fühlen (One could feel a bit tired of souvenir shops and a bit annoyed by sellers).

However, despite this negative evaluation, 24 per cent of both English and German tourists know about the cultural and historical value of the trulli, now a Unesco World Heritage site. On the other hand, Italian tourists do not even mention the fact that Alberobello is on the list of Unesco World Heritage sites. 
Moreover, what can be noticed is the use of value judgements referring to the appearance of Alberobello and its trulli. English writers consider them strange, bizarre-looking, unusual, funny, bizarrely lively, like French chateaux designed for dwarves, and German writers see them as Zwergenhäuser (houses for dwarves), einzigartig (unique), ungewöhnlich (unusual) and niedlich (sweet). In other words, 'out-of-the-ordinariness' and 'unfamiliarity' are the main aspects that both English and German tourists associate with the trulli.

\subsection{The semantic field of food and drink}

Salento fascinates English and German tourists for its landscape, the Baroque style, the popular music and the food (D'Egidio 2009). Therefore, the analysis of the semantic field of 'food and drink' was useful to understand the perception of Puglia's gastronomic quality and whether food is a pull factor in attracting tourists to Puglia. Words such as food, cuisine and dishes were investigated with the aim of discovering how English, Italian and German writers define the quality of Puglian food.

Analysis in the Italian corpus showed that only 16 per cent of the Italian writers highlight the excellent quality of Puglian cuisine, by using adjectives such as ottima (great) and buona (good), while 84 per cent list and specify the local food they tried without expressing any opinion, as in examples (15) and (16):

(15) Alimenti caratteristici della cucina Pugliese sono essenzialmente l'olio di oliva extravergine, la pasta di grano duro, il pesce sempre freschissimo, le cozze ed i ricci di mare (Typical food of Puglia cuisine is mainly extra virgin olive oil, durum wheat pasta, fish always very fresh, mussels and sea urchins).

(16) Tanti prodotti enogastronomici: vino, frutta e soprattutto olio (Many wine and food products: wine, fruit and above all oil).

Besides listing the local produce they tried, all the English and German writers underline the high quality and tastiness of the local food. Adjectives found in both corpora are: superb, sublime, gorgeous, simple, fresh, rural, delicious, peasant, tasty, great, as illustrated in examples (17) to (21):

(17) It is said that 'la cucina Pugliese nasce come cucina povera' (the cuisine of Puglia was born as the cuisine of poverty) and it is certainly true that this poor area has made the very best of its local produce. 
(18) The real reason for coming here is the food and wine.

(19) What you might call the "industrialization" of food doesn't exist in Puglia; food comes straight from the land or sea to be eaten. It isn't processed, it's simple, fresh and delicious.

(20) Die Küche Apuliens ist einfach und rustikal (Puglia cuisine is simple and rustic).

(21) Die Stärke der traditionellen apulischen Küche beruht auf der Verwendung frischer, regionaler Produkte (The excellence of Puglia's traditional cuisine lies in the use of fresh and regional produce).

The collocational profile of food or cuisine suggested that food is judged positively by all English and German writers, and adjectives such as simple and poor are not to be perceived negatively. Food may indeed be a cultural attraction and a reason why English and German tourists would visit Puglia.

The large amount of local produce mentioned in the English and German corpora gave an insight into what is generally perceived as traditional Puglian food and hence what tourists from the UK and Germany eat or drink when in Puglia, as clearly shown by examples (22) to (26):

(22) The region's most popular pasta variety, orecchiette (little ears), mixed with broccoli and a smidgen of chopped chilli. Follow that with any of the locally caught fish.

(23) A type of pasta typical to Puglia - parmigiana (aubergine layered with mozzarella and tomato sauce) and calzone, an Italian version of a Cornish pasty.

(24) Puglia produces a fifth of Italy's wine and two-thirds of the country's olive oil, making it impossible not to eat well.

(25) Die Orecchiette-Nudeln werden traditionell mit einem brokkoliartigen Gemüse oder mit einer Tomatensoße serviert (Orecchiette-noodles are traditionally served with a type of broccoli or tomato sauce).

(26) Regionaler Produkte... die wichtigsten wohl Hartweizen, frische Gemüse, Olivenöl und Wein sind (Regional products... the most important are durum wheat, fresh vegetables, olive oil and wine).

As illustrated in Table 3, travel writers mention the same local products, namely pasta, vegetables, fish, bread, olive oil and wine but with a different frequency: 
Table 3: English, German and Italian frequency lists of local food

\begin{tabular}{|ll|ll|lr|}
\hline \multicolumn{2}{|c|}{ ENGLISH } & \multicolumn{2}{c|}{ GERMAN } & \multicolumn{2}{c|}{ ITALIAN } \\
\hline Wine & $78 \%$ & Wein & $78 \%$ & Pesce & $50 \%$ \\
Olive oil & $56 \%$ & Olivenöl & $47 \%$ & Pasta & $35 \%$ \\
Pasta & $54 \%$ & Pasta/Nudeln & $34 \%$ & Verdura & $19 \%$ \\
Fish & $32 \%$ & Fisch & $34 \%$ & Pane & $17 \%$ \\
Bread & $32 \%$ & Gemüse & $21 \%$ & Vino & $15 \%$ \\
Vegetables & $21 \%$ & Brot & $13 \%$ & Olio & $14 \%$ \\
\hline
\end{tabular}

What can be noticed in Table 3 is that the frequency of the local products is almost identical in the English and German list, and that the first two items in these lists are the last ones in the Italian list.

Interestingly, in most cases, the English and German writers actually use the Italian terminology. The adoption of Italian words injects little doses of Italianness into the discourse and adds a notion of 'authenticity' and 'uniqueness' to Puglian food. As Dann (1996: 184) observes, within the language of tourism, borrowings occur more frequently than in the general language and, more specifically, in the domain of gastronomy, which are thus rendered out-of-the-ordinary and unique. Culture-bound borrowed lexical items, such as orecchiette (little eared pasta) and parmigiana (aubergines baked with cheese and tomato sauce), catch the readers' attention and add a touch of the 'exotic' and local colour. Moreover, the English and German writers often add an explanation, a description or a comparison to similar domestic products to increase the readers' understanding.

Further investigation of the word oil demonstrated that the English and German writers state that Puglia is the Italy's largest or one of the largest producers, as shown in examples (27) and (28):

(27) Puglia is the olive oil capital of Italy.

(28) 40 Prozent des gesamten Olivenöls Italiens stammt aus Puglia (40 per cent of all olive oil in Italy comes from Puglia).

Similarly, the investigation of the word wine showed that expressions linked to the production of wine occurred 36 times in a total of 101 entries in the English corpus and 22 times in a total of 56 entries in the German corpus, while in the Italian one they showed a restricted range of frequent collocates which did not prove useful for the analysis. 
Furthermore, the English and German writers' focus is on the taste of wine. In the English corpus the concept of tastiness is expressed by adjectives such as good, authentic, fleshy, strong, rich. These and similar adjectives occurred 15 times in a total of 101 entries. Adjectives such as fruchtig (fruity), weich (soft), trocken (dry), harmonisch (harmonious) und angenehm (pleasant), on the other hand, occurred 12 times in a total of 56 entries in the German corpus, as in examples (29) to (31):

(29) Discovering her indigenous grapes, authentic wines and passionate producers.

(30) The local red wine is strong and rich, while the less popular white wine should be drunk very cold.

(31) Der Wein ist sehr weich, trocken, harmonisch und angenehm" (Wine is very soft, dry, harmonious and pleasant).

In both corpora it turned out that local wines, such as Salice Salentino, Primitivo, Negroamaro, are labelled 'DOC' (Denominazione di Origine Controllata [Controlled Designation of Origin]) or 'IGT' (Indicazione Geografica Tipica [Indication of Geographic Tipicity]). The fact that a number of English and German writers know about the technical denominations of 'DOC' or 'IGT' for local wines is a sign of their extensive knowledge about wine production and their particular interest in tasting authentic wines, which meet high standards of quality control.

Furthermore, as part of the collocational profile of the word oil in the other two corpora, the words olive and Oliven were noted. The lexico-collocational analysis showed that they collocate with groves (28 times) and Olivenhaine (18 times), as in (32), (33), (35), (36), or trees (48 times) and Bäume (13 times), as in (34), (35) and (37):

(32) The endless olive groves are wonderful to gaze at.

(33) For nestled in among the olive groves are a number of masseria springing up like oases in the desert.

(34) The centuries-old olive trees and assorted pretty landscapes.

(35) Alte Olivenhaine voll knorrig gewundener Bäume (Old olive groves full of gnarled and wonderful trees).

(36) Die endlos scheinenden Olivenhaine glitzern silbrig, die rote Erde bildet einen scharfen Kontrast. Manche der knorrigen Bäume sind mehr 
als 600 Jahre alt (Endless shining olive groves glitter silvery, the red earth makes a strong contrast. Some of gnarled trees are more than 600 years old).

(37) In der kargen Landschaft fallen knorrige Olivenbäume, weiß Gehöfte und vereinzelte Häuser auf (In the barren landscape there are gnarled olive trees, white masserie and isolated house).

Since such landscapes are not to be found in Britain or Germany, olive groves and trees are perceived as something 'out-of-the-ordinary' and 'unfamiliar', and for this reason they are worth gazing at. This idea is conveyed in particular by adjectives, found in both corpora, such as gnarled, endless, old and wonderful.

\section{Discussion and conclusion}

With globalisation becoming more prevalent and with the growing use of English as a lingua franca, recent studies are focusing on the importance of understanding how English is being used as a global language by speakers of other languages. This is particularly helpful in the field of tourist promotion, as even if English speaking countries are the main targets of tourist material, "the readership of English texts may in fact consist of members of a range of cultures" (Poncini 2006: 139). Most tourist material, indeed, is available in only two languages, the local language and English. Yet it is read by tourists with different cultural and linguistic backgrounds.

The analysis conducted so far has been an attempt to show to what extent the tourist gaze may be used to recontextualise tourist material in order to produce English language texts that will be read by tourists from a range of cultures representing a model of 'global gaze'. Thus, the German culture has been taken into consideration as a sample in order to identify a number of common patterns of English-speaking and non-English speaking countries.

The results demonstrated that the Italian tourists' gaze is, indeed, different from the English and German tourists' gaze on Puglia. More specifically, even though they all go to Salento, the southern area of Puglia, visit Lecce and gaze at its sea, beaches and coasts, they evaluate them differently. To the English and German travel writers these places are worth visiting due to the fact that they are 'undiscovered', 'unspoilt', 'untouched', 'forgotten', 'tourist-free', 'wild', and 'unexploited'. These adjectives convey their need for places 'off the beaten track', which can confer authenticity. This is demonstrated by the analysis of the small towns of Otranto and Alberobello ('touristy'), and the analysis of the surrounding landscape (olive groves and trees are considered 'out-of-ordinary' and 
'unfamiliar'). Furthermore, the search for authenticity and uniqueness by English and German tourists is evident when taking into account their extensive interest in the cultural and historical value of the trulli, the authentic wines and the traditional Puglian food. On the other hand, when describing Salento, Lecce, sea, beaches and coasts, Italian tourists make use of an expressive language, namely abstract nouns in a figurative sense, to transmit their perceptions. They appreciate the 'touristy' town Alberobello and gaze at its souvenir shops.

Moreover, the different tourist gazes on Puglia made it possible to classify English, Italian and German writers in terms of tourist type. English and German tourists can be defined as 'anti-tourists' (Dann 1996: 165), since they try to detach themselves from popular, codified and over-used tourist routes, as 'travellers' and not 'tourists' (Urry 2002), as they denigrate tourist superficiality and passivity. To use Cohen's classification of tourists (1972), they can be 'explorers', since they try to get off the beaten track as much as possible, avoid any contact with 'tourists', seek unfamiliar and out-of the-ordinary aspects, and are wholly immersed in the host culture (D'Egidio 2009). On the other hand, Italian tourists can be considered 'mass tourists' or, to be more precise, 'independent mass tourists' (Cohen 1972), as their travel experience is superficial, commodified and inauthentic.

Judging by the analysis of landmarks and elements of attractions in Puglia, following Urry and Larsen (2011: 30), it is evident that "we can talk of the globalising of the tourist gaze, as multiple gazes have become core to global culture", even though "visitors from different parts of the world do not share the same knowledge of local geography, culture, specialties" (Poncini 2006: 139) and do not have a common background.

The results obtained seem to suggest that in order to produce more effective tourist texts, one possible solution could be the production of two kinds of tourist materials: 1) materials taking into account the common traits of Italian tourists, that is to say a model of local/insider gaze, and 2) not a 'translation' but a reformulation and recontextualisation of tourist materials in English as a lingua franca. In other words, they should represent more than one specific target, i.e. English speaking countries, hence embedding emerging common patterns of the global tourist gaze, given the high similarity between behaviours among tourists coming from different countries. More specifically, tourist texts in English should embed what "Outsider" tourists, as defined by Katan (2012: 90), see, hear, taste, and how they relate to, interpret and perceive a tourist destination, as being part of 'out-of-the-ordinary'. 
The present study is by no means exhaustive, and further research involving other cultures is needed to identify a more articulated model of the global tourist gaze and to further confirm the common patterns identified so far.

\section{Note}

1. Some parts of this study, referring to the analysis of online travel articles, were originally presented at the VII Congress of European Society for Translation Studies, "Translation Studies: Centres and Peripheries" (Germersheim, 28 August - 1 September 2013).

\section{References}

Cohen, Erik. 1972. Towards a sociology of international tourism. Social Research 39 (1): 164-182.

Collins COBUILD advanced dictionary of English. 2012. (Seventh edition). Boston: Heinle and Heinle Publishers.

Crowston, Kevin and Marie Williams. 2000. Reproduced and emergent genres of communication on the World Wide Web. Information Society 16 (3): 201-215.

Dann, Graham M. S. 1996. The language of tourism: A sociolinguistic perspective. Wallingford, U.K.: Cab International.

D'Egidio, Angela. 2009. Eyeing Puglia. Comparing the tourist gaze in English, Italian and German travel articles. Rivista Internazionale di Tecnica della Traduzione 11: 201-212.

Francesconi, Sabrina. 2007. English for tourism promotion: Italy in British tourism texts. Milano: Hoepli.

Gorton, Alex. 2007. Why this will never be the new Tuscany. The Guardian, 20 May. Available at: http://www.theguardian.com/travel/2007/may/20/ escape.italy. Accessed on 10 January 2013.

Gotti, Maurizio. 2006. The language of tourism as a specialized discourse. In O. Palusci and S. Francesconi (eds.). Translating tourism linguistic/cultural representations, 15-34. Trento: Editrice Università degli Studi di Trento.

Katan, David. 2012. Translating the tourist gaze: From heritage and 'culture' to actual encounter. Pasos, Special Issue 'Language and culture in tourism communication', 10 (4): 83-95. 
MacCannel, Dean. 1989. The tourist: A new theory of the leisure class. New York: Schocken Books.

Manca, Elena. 2007. Beauty and tranquillity in the language of tourism: Linguistic and cultural reasons. In C. De Stasio and O. Palusci (eds.). The language of tourism. Turismo e mediazione, 113-128. Milano: Edizioni Unicopli.

Manca, Elena. 2008. From phraseology to culture: The case of qualifying adjectives in the language of tourism. In U. Roemer and R. Schulze (eds.). International Journal of Corpus Linguistics, Special Issue 'Patterns, meaningful units and specialized discourses', 13 (3): 368-385.

Margarito, Mariagrazia. 2000. La bella Italia des guides touristiques: quelques formes de stéréotypes. In M. Margarito (ed.). L'Italie en stéréotypes. Analyse des textes touristiques, 9-36. Paris: L'Harmattan.

Poncini, Gina. 2006. The challenge of communicating in a changing tourism market. In O. Palusci and S. Francesconi (eds.). Translating tourism. Linguistic/cultural representations, 137-153. Trento: Editrice Università degli Studi di Trento.

Scott, Mike. 2012. WordSmith Tools, version 6. Liverpool: Lexical Analysis Software.

Tognini Bonelli, Elena. 2001. Corpus linguistics at work. Amsterdam: John Benjamins.

Tognini Bonelli, Elena and Elena Manca. 2002. Welcoming children, pets and guests. Textus XV: 317-334.

Urry, John. 2002. The tourist gaze. (Second edition). London: Thousand Oaks, New Delhi: Sage Publications.

Urry, John and Jonas Larsen. 2011. The tourist gaze 3.0. London: Sage Publications. 